\title{
THE USE OF BIOTECHNOLOGY IN HOP (Humulus lupulus L.) IMPROVEMENT
}

\author{
JURAJ FARAGÓ ${ }^{1,2}$, IVANA PŠENÁKOVÁ ${ }^{2}$, NATÁLIA \\ FARAGOVÁ $^{1}$ \\ ${ }^{1}$ Plant Production Research Centre, Research Institute of Plant Production (RIPP), \\ Bratislavská cesta 122, Piešt'any, SK-921 68, Slovak Republic (farago@vurv.sk) \\ ${ }^{2}$ Department of Biotechnology, University of SS. Cyril and Methodius, J. Herdu 2 , \\ Trnava, SK-917 01, Slovak Republic
}

\begin{abstract}
Hop (Humulus lupulus L.) is a clonally propagated, dioecious, perennial, climbing plant used commercially for their secondary metabolites. The resins containing $\alpha$ - and $\beta$-acids, and essential oils produced by the lupulin glands, present on the female flowers are used to add bitterness, aroma and flavour to beer. Recently, flavonoids, including chalcones and flavanones, of hops have been shown to exert a variety of biological activities, including oestrogenic and anticancerogenic characteristics. In this review, we provide a overview of the techniques and opportunities presented by the integration of plant biotechnology into hop improvement. The use of tissue culture techniques such as micropropagation, meristem culture, in vitro storage, adventitious shoot induction, callus culture and cell suspension culture in hops are briefly reviewed. The usefullness of genetic transformation technology to introduce novel traits into hop is also discussed.
\end{abstract}

Keywords: hops, biotechnology, tissue culture, genetic transformation, secondary metabolites

\section{Introduction}

The hop plant (Humulus lupulus L.) is widely cultivated throughout the temperate zones of the world for its female inflorescences (commonly referred to as 'cones'), which are used in the brewing industry to add bitterness, aroma and flavour to beer. Before using in brewing industry, hops were traditionally used as herbal medicines, mainly for the treatment of sleeping disorders, as a mild sedative, and for the activation of gastric functions as bitter stomachic (ZANOLI and ZAVATTI, 2008). Currently, the beer brewing industry accounts for $98 \%$ of the world use of hops (MOIR, 2000). Hop oil fractions and hop extracts are also used as flavoring products in nonalcoholic beverages and foods.

In addition to improving the agronomic traits, hop breeding also aims to tailor the components of the plant important for brewing to the demands of the market. Thus, there is an ever increasing need for cultivars exhibiting superior performance in multiple traits, such as high levels of $\alpha$-acids, excellent flavour, good storage stability and high yield.

Until very recently, plant breeding relied solely on the accumulated experience of generations of farmers and breeders, that is, on sexual transfer of genes between related plant species. In the last 150 years, however, plant breeding has developed into a complex discipline that now incorporates information from many branches of science and mathematics. The most recent development is the utilization of biotechnology for plant improvement (PAULS, 1995). For the purposes of this review, 
plant biotechnology can be defined as the application of tissue culture and molecular genetics to develop or produce a commodity from plants. Plant tissue culture refers to the maintenance and propagation of plant parts (organs, tissues, and single cells) in biologically pure (axenic) and controlled environments, while molecular genetics includes the techniques for isolating, characterizing, recombining, and transferring discrete fragments of DNA containing genes coding for specific traits into other, nonrelated, genetic backgrounds.

The purpose of this review is to provide a brief overview of the techniques and opportunities presented by the integration of plant biotechnology into improvement of hop (H. lupulus L.) species.

\section{Biological characteristics of hops}

\subsection{Taxonomy}

The genus Humulus belongs to the family of Cannabinaceae, previously placed in the order Urticales, but in 2003 incorporated in the order Rosales (BREMER et al., 2003). The genus consists of three species: Humulus lupulus Linneus, Humulus japonicus Siebold \& Zucc. and Humulus yuannensis Hu (SMALL, 1978; NEVE, 1991). The centre of origin of the genus is considered to be China, because all Humulus species have been found in this area (NEVE, 1991; MURAKAMI et al., 2006). H. japonicuc is native to Japan, Taiwan and China, while H. yuannensis is native to high altitudes of the Yunan Province in China. H. lupulus, which is almost exclusively cultivated for brewing purposes, was first domesticated in central Europe in the middle of the ninth century, and is currently naturalized throughout the north temperate regions of the world as well as some temperate regions in Australia, South Africa, and South America (CHADWICK et al., 2006). Based on their morphological characteristics and geographical locations SMALL (1978) classified the species Humulus lupulus into five taxonomic varieties: var. lupulus Small (European hops), var. cordifolius Small (Japanese hops), var. neomexicanus Nelson \& Cockerell, var. pubescens Small and var. lupuloides Small (North American hops).

\subsection{Botany}

Common hop is a dioecious perennial plant which produces new shoots each year in early spring from rhizomes of an underground rootstock. The outgrowing climbing vine grows up to 6-9 $\mathrm{m}$ in length and senesces to the perennial rootstock in autumn (KRIŠTÍN, 1987; RYBÁČEK, 1980). The stems twist around their support in a clockwise direction. The dioecious nature of the plant means that the male and female flowers are on separate plants (Fig. 1). However, individual monoecious plants have been found in some wild North American hop populations (HAUNOLD et al., 1993). The male flowers are 7-14 cm long racemes (Fig. 1A), while the female inforescences are 2.5-5.5 cm long cone-like catkins (strobiles, Fig. 1B), made up of overlapping flattened membranaceous bracts. At the base of cone bracts a number of yellow glandular trichomes can be found, which secrete a resinous substance, known as lupulin (RYBÁČEK, 1980). Only female plants are cultivated in hop gardens, while 
male plants are essential in hop breeding programs aimed at developing new varieties through controlled hybridization (RYBÁČEK, 1980; NEVE, 1991). The cultivated hop is a short-day plant that initiates flowering when the plant is at a critical size (about $6 \mathrm{~m}, 20-24$ nodes) and critical daylength is about $16 \mathrm{~h}$, beyond which flowering cannot be induced (VILLACORTA et al., 2008). The minimum daylength, below which the plant ceases vegetative growth and forms dormant terminal buds, is considered to be $8-10 \mathrm{~h}$. From the cytological point of view, cultivated hop is a diploid $(2 \mathrm{n}=20)$ species with heteromorphic sex chromosomes (XX in female plants, $X Y$ in males) (DANILOVA and KARLOV, 2006).

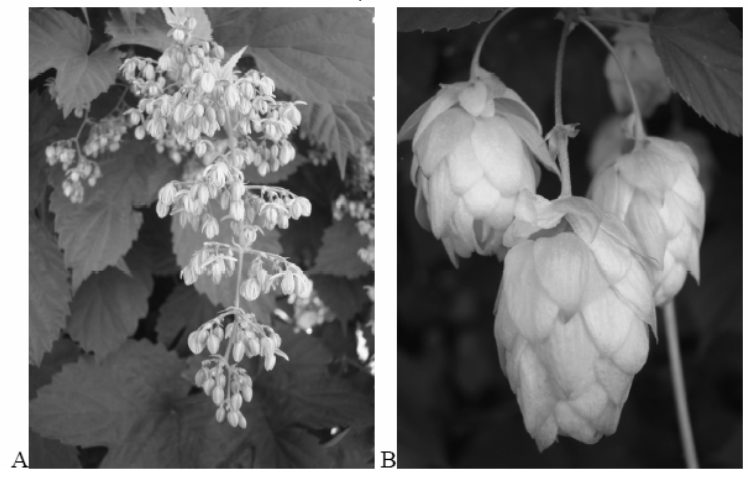

Fig. 1. Male (A) and female (B) inflorescences of hop. (Foto: J. Farago)

\subsection{Breeding}

At the earliest hop plants were collected in the wild. According to WILSON (1975) the cultivation of hops started in Germany the middle of the ninth century, between A.D. 859 and 875 . The interest in selection of new and improved hop variants grew significantly during the nineteenth century when selections were made by the growers from variants observed in their own gardens (MOIR, 2000). Hop breeding started with these clonal selections from adapted wild hops, which has lead to cultivation of lanraces like Fuggle and Goldings in England, Tettnanger and Hallertauer Mittlefruer in Germany and Saazer in Czech Republic. These varieties and their derivatives are still in production today and are typical representatives of European aroma hops with relatively low yield and resin content (STAJNER et al., 2008). Modern cultivars of hops are derived by sexual hybridization which allows the tailoring of hop aroma and bitterness, as well as the introduction of new traits. Current breeding practices are aimed primarily at improving the disease resistance (Verticillium wilt, downy mildew, and powdery mildew), increasing the resin content, and combining traits by utilization of cultivars and breeding lines or wild hops with favourable properties. Today's basic sources of plant breeding material are maintained in hop germplasm collections, which have been established at main hop breeding centres (STAJNER et al., 2008).

Hop is sensitive to different types of pathogens, such as viruses, viroids, bacteria and fungi, which adversely affects its yield and product quality. There is still a shortage of effective chemicals for pest and disease control, and crop yields are consequently subject to dramatic seasonal variation. In most hop-growing countries 
one of the main objectives of recent breeding programs have been to raise the $\alpha$-acid content. There is also an increased demand for improved varieties of hops which differ in their resin content, produce different bitterness levels in beers and have increased ability to preserve beer. In some countries, for example in Australia and England, tetraploid parents play an important role in hop breeding, as they can be crossed with diploids to produce triploid progeny. The large number of grown hop varieties fall generally into two groups: alpha (or bitter hops) and aroma hops. Bitter hops are high alpha acid content, whereas aroma hops have much lower content $(<5 \%)$.

\subsection{Phytochemistry}

More than 1000 chemicals have been identified from hops (CHADWICK et al., 2006). The main structural classes of chemical compounds identified in hops include terpenes, bitter acids, and chalcones. Hundreds of terpenoid compounds identified in the essential oil component of hops account for $0.3-1.0 \%$ of strobile weight. The study of the composition of hop essential oils revealed that hydrocarbons usually constitute $40-80 \%$ of the oil and, apart from a few simple alkanes, they all are of terpenoid origin. A complex group of at least 40 acyclic, monocyclic, bicyclic, and tricyclic sesquiterpenes is usually dominated by $\alpha$-humulene, $\beta$-caryophyllene, and farnesene. Of the monoterpenes, myrcene is the primary component of hop essential oils (MOIR, 2000; ROBERTS and LEWIS, 2002). The analysis of hop essential oils helps in determining both hop quality and varietal discrimination (ROBERTS and LEWIS, 2002).

The bitter acids comprise $5-20 \%$ of hop strobile weight. They are classified as either $\alpha$-acids or $\beta$-acids which are, respectively, di- or tri-prenylated phloroglucinol derivatives. In addition, they each contain a 3-, 4-, 5-, or 6-carbon oxo-alkyl side chain (VERZELE and KEUKELEIRE, 1991). The bitter acids are present in hop cones as a complex mixture of variable composition and concentrations, depending on the variety and growing conditions. The $\alpha$-acids, particularly humulone (35-70\% of total $\alpha$-acids), cohumulone (20-65\%), and adhumulone (10-15\%) are regarded as the most important constituents in determining the quality of hops (VERZELE and KEUKELEIRE, 1991; CHADWICK et al., 2006). The biochemistry (biosynthesis, isomerization, oxidation and degradation) of hop bitter acids have been extensively studied (VERZELE and KEUKELEIRE, 1991; GOESE et al., 1999).

The dried hop cones contain 4-14\% polyphenols, mainly phenolic acids, prenylated chalcones, flavonoids, catechins and proanthocyanidins (GERHÄUSER, 2005). The flavonoids of hops include flavonol glycosides, condensed tannins, and prenylflavonoids (STEVENS et al., 1998). The majority of known flavonoids from hops can be considered as derivatives of the compound 2',4,4',6'-tetrahydroxy-3'prenylchalcone, commonly known as desmethylxanthohumol (DMX) (CHADWICK et al., 2006). The most abundant and most important prenylated flavonoid in fresh, and properly preserved hops, is the chalcone xanthohumol, present at concentrations of $0.01-0.5 \%$ (STEVENS et al., 1999). Recently, xanthohumol (XN) was identified as a broad-spectrum cancer chemopreventive agent with inhibitory mechanisms in the initiation, promotion and progression phase of carcinogenesis (MIRANDA et al., 1999). In addition, another prenylated flavonoid of hop, 8-prenylnaringenin (8-PN) was identified as a very potent phytoestrogen (MILLIGAN et al., 1999). 


\section{Biotechnology of hop improvement}

\subsection{Micropropagation}

Traditionally, hop cultivars are vegetatively propagated by layering young vines under the soil or by rooting soft-wood nodal cuttings during the growing season (NEVE, 1991). Tissue culture techniques can be used as alternative means of plant multiplication. The clonal propagation of plants in vitro is called micropropagation. Thus micropropagation can be characterized as the multiplication of genetically identical individuals by asexual reproduction. A significant advantage offered by the aseptic methods of clonal propagation over the conventional methods is that in a relatively short span of time and space a much larger number of plants can be produced from an individual (CHAWLA, 2002).

In vitro micropropagation of hop is feasible starting from node cuttings, apical tip explants (ROY et al., 2001; SMÝKALOVÁ et al., 2001), meristems (ADAMS, 1975), and parts of the shoot or leaves (BATISTA et al., 1996; PEREDO et al., 2006). ROY et al. (2001) used nodal explants of hop variety H138 to test the effect of plant growth regulators and different media formulations on shoot multiplication efficiency. They achieved efficient culture establishment (96.6\% of explants) on Murashige and Skoog (MS) media supported with plant growth regulators indoleacetic acid (IAA, $0.57 \mu \mathrm{M}$ ) and 6-benzylaminopurine (BA, $2.22 \mu \mathrm{M})$. However, in subsequent multiplication media, addition of the cytokinin $N$-phenyl- $N^{\prime}-1,2,3$-thidiazol-5-ylurea (TDZ) resulted in significantly higher number of shoots and nodes generated per explant compared to media containing BA, 6- $(\gamma, \gamma$-dimethylallylamino)purine (2iP) or kinetin (KIN). SMÝKALOVÁ et al. (2001) developed an efficient in vitro micropropagation system for Czech and several foreign hop mericlones using low sugar, starch-Gelrite media. The use of this medium resulted in lower cost of micropropagation of healthy hop cultures without exhibition of vitrification.

In clonal propagation of plants, such as commercial cultivars of hops, it is very important to keep the genetic stability of recovered plants. However, due to genetic and epigenetic changes induced by the in vitro culture environment, the phenotype of the regenerated plants may be different from the original mother plant in some cases (KAEPPLER and PHILLIPS, 1993). The use of molecular techniques as a method for evaluating genetic stability of tissue culture derived plants is frequently described in the literature since molecular markers can characterize the fenomenon of somaclonal variation with much greater precision and lesser effort than karyological and phenotypic analyses. In hops, PEREDO et al. (2006) used the amplified fragmentlength polymorphism (AFLP) and methylation-sensitive amplified polymorphism (MSAP) techniques to characterize the genetic and epigenetic variation in hop plants regenerated from sequential subcultures of organogenic calli. They detected no major genetic rearrangements in the callus-derived plants since none of the AFLP loci were polymorphic, however, epigenetic changes due to a demethylation process were detected by the MSAP technique. The epigenetic changes were found to increase when the calli were maintained over a longer period in tissue culture.

Micropropagation is often used to mass propagate virus-free stock plants obtained by the use of meristem culture technique. 


\subsection{Meristem culture}

Among the prevalent tissue culture techniques used in agricultural biotechnology, the meristem and shoot tip culture have been exploited at a much wider scale primarily due to their potential applicability in diverse areas, such as virus elimination and production of virus-free stock plants, rapid clonal multiplication of vegetatively propagated plants, and germplasm preservation of both vegetatively and seed propagated crop species (NEHRA and KARTHA, 1994).

The meristem-tip propagation technique used for production of virus-free plants was the first direct application of tissue culture technology to hop improvement by VINE and JONES (1969) at East Malling Research Station in United Kingdom. This approach proved to be very successful and was extended by GIPPERT et al. (1974) in Germany, by ADAMS (1975) in the UK, by KUBO et al. (1975) in Japan, by SAMYN and WELVAERT (1983) in Belgium, by POPOV et al. (1985) in the previous USSR, and by PROBASCO and WINSLOW (1986) in the USA. More recently the meristem culture technique was applied to produce virus-free stock plants also in Czech Republic (SVOBODA, 1992) and Slovakia (FARAGÓ and NEŠŤÁKOVÁ, 1998), respectively. In our laboratory at RIPP Pieštany, meristem culture was successfully applied to all ten cultivars tested. In average around $70 \%$ of meristems developed 1 to 4 shoots during the 28 day-long culture period on MSC induction medium. In total 299 mericlones were obtained and subjected to thermotherapy. The viability of cultures after thermotherapy was in average 65\% (FARAGÓ and NEŠŤÁKOVÁ, 1998). Starting with year 1996, the hop yards in Slovak republic were replanted with meristem culture-derived virus-free plants, which caused a substantial increase in yield parameters in subsequent years (for example almost doubled $\alpha$-acid content) (KOŠÚTOVÁ, 2002, pers. comm.). Now, the cultivation area of meristem culturederived hops In Slovakia is cca. 350 ha, representing about $0,8 \%$ of the total production in the European Union.

Meristem-tip culture has been widely used for the production of virus-free plant material in many species propagated mainly or exclusively by vegetative means. This technique enables the mother plant's genetic features to be conserved maximally in the regenerated plants. Virus elimination through tissue culture techniques, however, requires efficient plant regeneration systems.

\subsection{In vitro storage}

Hop germplasm is traditionally preserved in the form of field collections in areas of cultivation (REVILLA and MARTÍNEZ, 2002). However, conservation of plants in natural conditions is costly in terms of land utilization, labour and risks of losses through environmental hazards and diseases (WATT et al., 2000). In addition, virus diseases can accumulate in a field collection and be transferred to additional sites by vegetative propagation (REED et al., 2003). In vitro techniques have been found to be useful in ex situ conservation of a number of plant species (VILLALOBOS and ENGELMANN, 1995), including meristem culture-derived virus-free germplasms (FLETCHER et al., 1998). The storage longevity of in vitro collections depends on many important factors such as explant type, culture medium composition and culture conditions (AYNALEM et al., 2006; FARAGÓ et al., 2008) 
According to REED et al. (2003) the U.S. Department of Agriculture, ARS, National Clonal Germplasm Repository at Corvallis (Oregon, USA) maintains about 700 accessions of Humulus spp. germplasm in field collections, in pots in the screen house, and as tissue cultures in cold storage or as cryopreserved shoot tips in liquid nitrogen. At the Plant Production Research Centre - Research Institute of Plant Production (Piešt'any, Slovak Republic) we maintain more than 100 accessions of 10 cultivars (Osvalds clones 31, 72 and 114, Bor, Sládek, Siřem, Aromat, Lučan, Zlatan and Premiant) of predominantly meristem culture-derived virus-free hop genotypes (94 clones) using an optimized in vitro storage system (Tab. 1). Eight clones were introduced into in vitro culture in 1994, 94 clones in 1996 and 11 clones in the year 2000. Accessions are represented by 4 culture vessels (Baby Food jars, Fig. X) with 67 nodal explants in each. The subculture interval of cultures maintained in slow growth conditions ranges from 12 to 18 weeks. The cultures are regularly inspected for the potential occurrence of latent endocontaminating bacteria and the genetic stability of in vitro stored plant material is studied by molecular analysis of microsatellite markers (FARAGÓ et al., 2008).

Table 1. Optimization of tissue culture system for in vitro storage of meristem culture-derived hop germplasm. Variants marked with bold tetters were chosen to slow down the growth of in vitro shoot cultures.

\begin{tabular}{|c|c|}
\hline Parameter & Variant \\
\hline Mineral content of medium & Full strength, $1 / 2$ strength, $1 / 4$ strength \\
\hline Sugar concentration & $2,3,4$ and $6 \%$ glucose $; 2,3,4$ and $6 \%$ sucrose \\
\hline Solidifying agent & $2,5 \%$ Phytagel, $7 \%$ agar \\
\hline Plant growth regulators & $\begin{array}{l}\mathbf{0}, 0.05,0.1,0.15,0.2,0.25 \text { mg. } .^{-1} \text { BAP; } \mathbf{0}, 0.5,1.0,1.5,2.0 \\
\text { mg. } .^{-1} \mathrm{GA}_{3}\end{array}$ \\
\hline Culture vessel type & $\begin{array}{l}\text { Baby Food jars, industrial glass, Magenta vessels, test tubes } \\
\text { VitroVent vessels }\end{array}$ \\
\hline Explant type & $\begin{array}{l}\text { Growth tip, defoliated nodal segment, non-defoliated nodal } \\
\text { segment }\end{array}$ \\
\hline Cold treatment & $25 / 20^{\circ} \mathrm{C}, 15 / 10^{\circ} \mathrm{C}$ and $5 \pm 2^{\circ} \mathrm{C}$ \\
\hline Plant growth retardants & $\begin{array}{l}\text { ancymidol and paclobutrazol at } 0,1,2.5,5 \text { and } 10 \mu \mathrm{M} \text {; } \\
\text { mannitol and sorbitol at } 0,10,20,30 \text { and } \mathbf{4 0} \mathrm{mg}^{-1}\end{array}$ \\
\hline
\end{tabular}

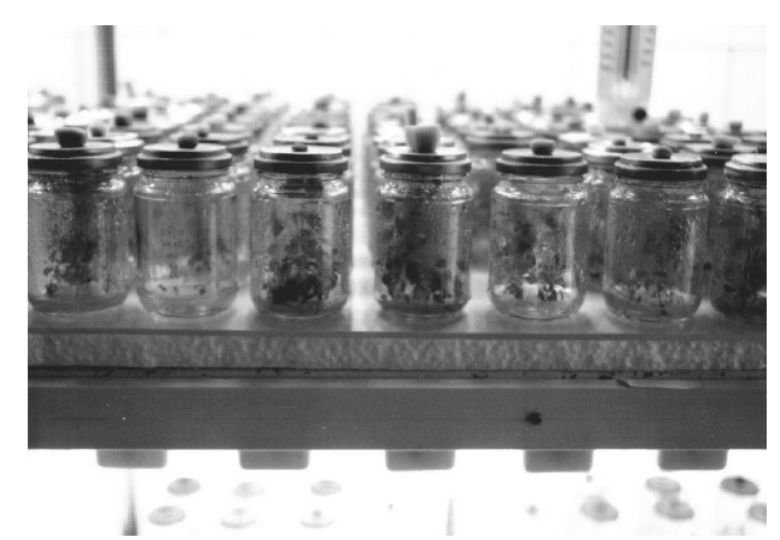

Fig. 2. In vitro storage of hop germplasm using the optimized slow growth method (Photo: J. Farago). 


\subsection{Adventitious shoot regeneration}

Beside the importance in different tissue culture techniques, regeneration of plants in in vitro culture is also an essential prerequisite for generation of transgenic plants. However, only a few reports are available to date on the regeneration of hop tissues other than meristems (MOTEGI, 1976; RAKOUSKÝ and MATOUŠEK, 1994; BATISTA et al., 1996; GURRIARÁN et al., 1999). MOTEGI (1976) reported a successfulr regeneration of plants from callus cultures derived from leaf explants. RAKOUSKÝ and MATOUŠEK (1994) published a protocol for direct organogenesis of two commercial Czech hops on media containing BAP or zeatin. They achieved the highest regeneration of shoots from either petioles or internodes at frequencies $21 \%$ and $52 \%$, respectively. BATISTA et al. (1996) tested the organogenic ability of petiole and stem segments of two hop varieties on three different basal media supplemented with $0.025 \mathrm{mg} . \mathrm{l}^{-1}$ indole-3-acetic acid (IAA) and $2.0 \mathrm{mg} . \mathrm{l}^{-1}$ 6benzylaminopurine (BAP). These conditions induced rather heterogeneous responses, which depended mainly on the explant source and the genotype. The regeneration rate of cultures was also highly correlated with the production of green, nodular areas in the compact calli. GURRIARÁN et al. (1999) established a very efficient protocol for plant regeneration from two commercial hop cultivars, Brewers Gold and Nugget, and studied the morphogenetic potential of explants cultured on Adams modified medium supplemented with several concentrations of cytokinins and auxins. Regeneration rates of 60 and 29\% were achieved for Nugget and Brewers Gold, respectively.

We developed a highly efficient in vitro system for adventitious shoot regeneration from leaf and internode explants of 12 hop genotypes (Fig. 3; FARAGÓ and KOLLÁROVÁ, results not published). The highest percentage of plant regeneration $(52.7 \%)$ was achieved in genotype Zlatan/1/2T from internode explants cultured on media supplemented with $2.0 \mathrm{mg} . \mathrm{l}^{-1} \mathrm{BAP}$ and $2.0 \mathrm{mg} . \mathrm{l}^{-1} \mathrm{NAA}$ and when maltose was used as carbon source. All the tested genotypes produced adventitious shoots with average frequencies of $1.4-17.4 \%$. The regeneration frequency depended on the explant type (internode segment vs. leaf segment), auxin type (2,4-D vs. NAA), and Csource (glucose vs. maltose).

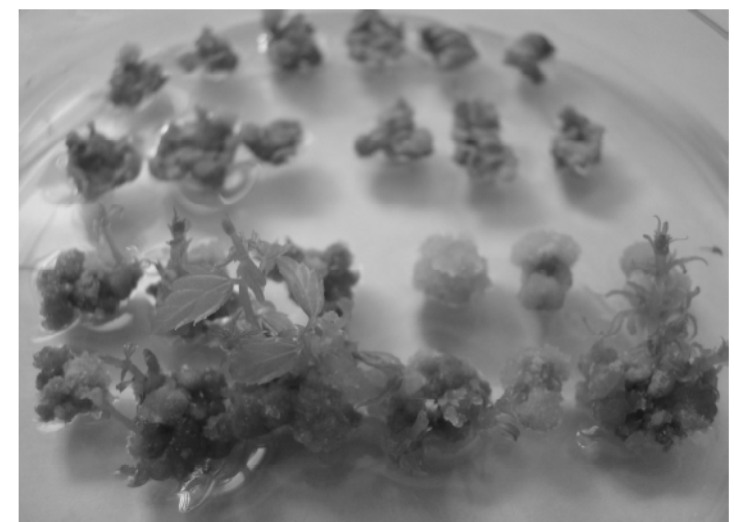

Fig. 3. Adventitious shoot regeneration from internode and leaf segment explants of the hop genotype K72/6/13 (Photo: J. Farago). 


\subsection{Callus culture}

Secondary metabolites of hops important for the brewing of beer include $\alpha$-acids and B-acids, however, another group of compounds present in hops, such as prenylated chalcones, xanthohumol, and desmethylxanthohumol, were recently found to exhibit interesting bioactive properties. The increased demand for medicinally important secondary metabolites increases the pressure to produce these compounds via alternative ways, especially using cell/tissue cultures and transgenic plants, respectively.

GRIFFIN and COLEY-SMITH (1968) first initiated hop callus cultures with the aim of study in aseptic conditions the infection process of fungus Pseudoperonospora humuli. Callus cultures in hops have been used experimentally to provide a source of regenerationg green nodular callus, for attempted selection of novel disease resistance to Verticillium albo-atrum in somaclonal variants, as well as providing a sterile source of leaf mesophyll protoplasts (CONNELL and HEALE, 1986b; HEALE et al., 1989). There were also attempts to establish regenerating, organogenic callus caltures from different types of explants (MOTEGI, 1976; BATISTA et al., 1996). Undifferentiated, white calli was produced from stem internodal segments, petioles, and leaf segments (CONNELL and HEALE, 1986b; HEALE et al., 1989; PŠENÁKOVÁ et al., 2009)

Currently, in line with a growing interest in the health benefits of medicinal plants, hop has received particular attention by the researchers due to the identification of pharmacologically relevant compounds, such as flavanones, chalcones, and phloroglucinol derivatives in hop cones (ZANOLI and ZAVATTI, 2008). Therefore, we study the possibility to establish a convenient in vitro system, based on the induction of callogenesis and establishment of cell suspension culture in hops for chemical analyses of constituents of in vitro cultures and for potential production of interesting flavonoids in in vitro culture systems (PŠENÁKOVÁ et al., 2009). Our system is based on induction of callus formation from two types of explants (internodal segments and leaf segments isolated from in vitro grown shoot cultures) on media containing the combination of auxin and cytokinin growth regulators BAP, NAA, and 2,4-D. Content of total polyphenols depended on culture conditions and ranged from 76.6 to $158.5 \mathrm{mg}^{-1}{ }^{-1}$ of gallic acid equivalent (GAE) in our callus cultures (PŠENÁKOVÁ et al., 2009).

\subsection{Cell suspension culture}

The culture of plant cells on a large scale has long been regarded as a potential source of secondary products. Large-scale tissue cultures were and are seen as a more convenient and reliable source of secondary products than intact plants (COLLIN, 2001). Plant cell suspension cultures offer the manufacturer independence from fluctuations in supply of the raw plant material that might have been created by vagaries in the climate, agriculture and political activities of the source country. Growing plant cells in vitro also permit a stricter control of the quality of the products. Problems connected with gathering, storing, processing and disposal of huge amounts of biomass, connected with extraction of active substances from in vivo plants are also 
solved (IONKOVA, 2007). Suspension cultures are of special interest due to their high growth rate and short cycle of reproduction.

The first cell suspension cultures of hops have been established by ROBBINS and RATCLIFFE (1984) to study the intracellular distribution of phosphate in hop cells growing in media with elevated phosphate concentrations. Later, cell suspension cultures were established with the aim of attempted production of $\alpha$-acid compounds (ROBBINS et al., 1985; FURZE et al., 1987). CONNELL et al. (1986a) studied the interaction of Verticillium wilt toxins with suspension cells. Various research groups performed some biological and phytochemical studies on hop callus and cell cultures. For example LANGEZAAL and SCHEFFER (1992) initiated cell suspension cultures of various hop cultivars and screened them for the presence of bitter acids by HPLC and of volatile compounds by capillary GC. However, they could not detect neither bitter acids nor volatile compounds. TREVISAN et al. (1997) studied the effect of elicitation on peroxidase activity in cell suspension cultures of one variety and four cultivars of hop.

We are interested in the potential of plant cell cultures to produce secondary metabolites, such as polyphenols, flavonoids and prenylated chalcons. As a model system we use hop callus and cell suspension cultures. We established cell suspension cultures from stabilized callus cultures of hop cultivar Osvald's clone 72 in liquid MS media containing different combinations of plant growth regulators. Cell suspension cultures were derived from two types of explants, stem segments and leaf segments and were cultured in two types of culture conditions. They showed high biomass accumulation (FW and DW), depending on the explant type, medium composition and culture conditions. The viability of cells (assessed as \% of TTC-positive cells) depended on the concentration of pectinase added to liquid media to liberate cells from cell clumps and ranged from $60.9-90.6 \%$ in media without pectinase to $36.2-65.4 \%$ in media with $1000 \mu$ pectinase. $\mathrm{g}^{-1}$ tissue FW. Content of total polyphenols depended on the type of in vitro culture and ranged $60.5-137.1 \mathrm{mg} . .^{-1}$ of GAE in comparison to 121.4 mg. $1^{-1}$ GAE in the source shoot cultures of hops. Using HPLC analysis, we were able to detect also the production of xanthohumol in cell suspension cultures of hops. The highest production of xanthohumol was observed in cell suspension cultures established from leaf segment-derived calli in medium containing $1.0 \mathrm{mg} . \mathrm{l}^{-1} \mathrm{BAP}$ in combination with $1.0 \mathrm{mg} .1^{-1} 2,4-\mathrm{D}$ without pectinase and cultured in dark conditions (PŠENÁKOVÁ et al., 2009).

\subsection{Genetic transformation}

Genetic engineering, or the ability to transfer genetic information from one species to another, has been possible for about three decades. The advantages of genetic engineering in hop breeding are obvious. In contrast to conventional breeding programs involving cross-pollination, the agronomic and qualitative traits of hops can be improved by inserting a single (or a few) gene(s) of interest with no other changes in the genome. A renewed interest in genetic transformation of hops has arisen from the finding that some hop compounds have remarkable bioactive properties showing strong estrogenic and anticancer activities, and therefore hop is regarded as strong candidate to molecular farming. 
Genetic transformation of hop using Agrobacterium tumefaciens is regarded as the most promising approach since hop in one of the natural hosts of this soil bacterium (DE CLEENE and DE LEY, 1976). However, only a few reports have been published on genetic transformation of hop using this technique, moreover, these experiments were not successful (BECKER, 2000), or irreproducible (ORINIAKOVÁ and MATOUŠEK, 1996). The first report on successful transformation of hop tissues by $A$. tumefaciens, and regeneration of transgenic plants of cv. Tettnanger was reported by HORLEMANN et al. (2003). Only two other papers have been reported on the successful production of transgenic hop plants containing gus reporter and/or nptII selection genes with the use of $A$. tumefaciens-mediated system [OKADA et al., 2003 (cv. Osvald's clone 72); ŠKOF and LUTHAR, 2005 (cv. Aurora)]. Recently SCHWEKENDIEK et al. (2007) reported on hop (cv. Tettnanger) transformation with a grapevine stilbene synthase gene using the system developed by Horlemann et al. (2003).

Biolistic transformation has proven to be a powerful and versatile technique and an alternative to Agrobacterium-mediated transformation. Recently BATISTA et al. (2008) developed a successful transformation system for hops using particle bombardment. They were able to establish a reproducible and efficient method for gene transfer and transgenic plant regeneration in hop var. Eroica.

\section{Conclusions}

Biotechnology is now applicable to many aspects of hop improvement. To be effective, plant biotechnology must be well integrated into established plant breeding programs and crop production practices. Plant cell cultures of hops can produce many valuable secondary metabolites including novel medicinal agents and in combination with synthetic chemistry, the tissue culture techniques can afford an attractive route to synthesis of complex natural products and related compounds of industrial importance. Application of biotechnology to hop improvement will also make diverse germplasm sources more valuable than ever before, because genetic material from different species, genera and even kingdoms can now be stably incorporated and expressed in hops. Very few reports on genetic transformation of hop have been published so far, and, in part, this can be explained by the difficulty to establish efficient plant regeneration systems that are still highly genotype dependent. Nevertheless, genetic transformation may be a powerful tool for improving agronomic and qualitative traits of hops as well as enhancing the productivity of secondary metabolites in transgenic cell cultures.

\section{References}

ADAMS, A.N.: Elimination of viruses from the hop (Humulus lupulus) by heat and meristem culture. J. Hort. Sci., 50, 1975, 151-160.

AYNALEM, H.M.; RIGHETTI, T.L.; REED, B.M.: Iron formulation affects in vitro storage of hops - An image analysis. In Vitro Cell. Dev. Biol. - Plant, 42, 2006, 405-410. 
BATISTA, D.; SOUSA, M.J.; PAIS, M.S.: Plant regeneration from stem and petiolederived callus of Humulus lupulus L. (hop) clone Branganca and var. Brewers's Gold. In Vitro Cell. Dev. Biol. - Plant, 32, 1996, 37-41.

BATISTA, D.; FONSECA, S.; SERRAZINA, S.; FIGUEIREDO, A.; PAIS, M.S.: Efficient and stable transformation of hop (Humulus lupulus L.) var. Eroica by particle bombardment. Plant Cell Rep., 27, 2008, 1185-1196.

BECKER, J.: Untersuchungen zur in vitro regeneration und genetischen transformation von hopfen (Humulus lupulus L.). Dissertation, University of Kaiserslautern, Kaiserslautern, Germany, 2000.

BREMER, B.; BREMER, K.; CHASE, M. W.; REVEAL, J. L.; SOLTIS, D. E.; SOLTIS, P. S.; STEVENS, P. F.; ANDERBERG, A. A.; FAY, M. F.; GOLDBLATT, P.; JUDD, W.S.; KALLERSJO, M.; KAREHED, J.; KRON, K. A.; LUNDBERG, J.; NICKRENT, D. L.; OLMSTEAD, R. G.; OXELMAN, B.; PIRES, J. C.; RODMAN, J. E.; RUDALL, P. J.; SAVOLAINEN, V.; SYTSMA, K. J.; VAN DER BANK, M.; WURDACK, K.; XIANG, J. Q. Y.; ZMARZTY, S.: An update of the angiosperm phylogeny group classification for the orders and families of flowering plants: APG II. Bot. J. Linn. Soc., 141, 2003, 399-436.

CHADWICK, L.R.; PAULI, G.F.; FARNSWORTH, N.R.: The pharmacognosy of Humulus lupulus L. (hops) with an emphasis on estrogenic properties. Phytomedicine, 13, 2006, 119-131.

CHAWLA, H.S.: Introduction to plant biotechnology. Science Publishers, 2002, 538 pp.

COLLIN, H.A.: Secondary product formation in plant tissue cultures. Plant Growth Reg., 34, 2001, 119-134.

CONNELL, S.A.; HEALE, J.B.: Development of an in vitro selection system for novel sources of resistance to Verticillium wilt in hops. In: Withers, L.; Alderson, P.G. (Eds.): Tissue culture and agriculture. Butterworths, London, 1986a, pp. 451459.

CONNELL, S.A.; HEALE, J.B.: In vitro use of Verticillium albo-atrum culture filtrates to select for disease resistance in regenerating callus cultures of hop (Humulus lupulus L.). Proc. Int. Symp. "Nuclear techniques and in vitro culture for plant improvement”, IAEA, Vienna, 1986b, 309-313.

DANILOVA, T.V.; KARLOV, G.I.: Application of inter simple sequence repeat (ISSR) polymorphism for detection of sex-specific molecular markers in hop (Humulus lupulus L.). Euphytica, 151, 2006, 15-21.

DE CLEENE M.; DE LEY, J.: The host range of crown gall. Bot. Rev., 42, 1976, 389466.

FARAGÓ, J.; NEŠŤÁKOVÁ, M.: Kultivácia meristémov v in vitro kultúre a produkcia bezvírusovej sadby pri chmeli obyčajnom (Humulus lupulus L.) [Cultivation of meristems in in vitro culture and production of virus-free stock plants in hop (Humulus lupulus L.)]. Zb. 4. odb. sem. „Nové poznatky z genetiky a šl'achtenia pol’nohospodárskych rastlín“, 1998, Piešt’any, 29-31.

FARAGÓ, J.; HUDCOVICOVÁ, M.; LAJCHOVÁ, Z.; VIDOVÁ, B.; VOJTEKOVÁ, P.; FARAGOVÁ, N.: In vitro storage of hop (Humulus lupulus L.) germplasm derived from meristem culture. Proc. Int. Sci. Meet. "Use of Genetic Resources of Cultivated Plants", Žatec, Czech Republic, 2008, 22-25. 
FLETCHER, P.J.; FLETCHER, J.D.; GROSS, R.J.: Potato germplasm: in vitro storage and virus eradication. New Zealand J. Crop Hort. Sci., 26, 1998, 249-252.

FURZE, J.M.; RHODES, M.J.C.; ROBBINS, R.J.: The use of agarose bead culture for the regeneration of single-derived colonies from protoplasts isolated from suspension cultures of Humulus lupulus. Plant Cell Tissue Organ Cult., 8, 1987, $17-25$.

GERHÄUSER, C.: Beer constituents as potential cancer chemopreventive agents. Eur. J. Cancer, 41, 2005, 1941-1954.

GIPPERT, R.; SCHMIDT, H.E.; SCHMELZER, K.: Einige Ergebnisse mit Spitzenmeristemkulturen bei hopfen (Humulus lupulus L.). Arch. Pflanzensch., 10, 1974, 7-13.

GOESE, M.; KAMMHUBER, K.; BACHER, A.; ZENK, M.H.; EISENREICH, W.: Biosynthesis of bitter acids in hops. Eur. J. Biochem., 263, 1999, 447---454.

GRIFFIN, M.J.; COLEY-SMITH, J.R.: The establishment of hop tissue cultures and their infection by Pseudoperonospora humuli under aseptic culture. J. Gen. Microbiol., 53, 1968, 231-236.

GURRIARÁN, M.J.; REVILLA, M.A.; TAMÉS, R.S.: Adventitious shoot regeneration in cultures of Humulus lupulus L. (Hop) cvs. Brewers Gold and Nugget. Plant Cell Rep., 18, 1999, 1007-1011.

HAUNOLD, A.; NICKERSON, G.B.; GAMPERT, U.; WHITNEY, P.A.; HAMPTON, R.O.: Agronomic and quality characteristics of native North American hops. J. Am. Soc. Brew. Chem., 51, 1993, 133-137.

HEALE, J.B.; LEGG, T.; CONNELL, S.: Humulus lupulus L.: In vitro culture; attempted production of bittering components and novel disease resistance. In: Bajaj, Y.P.S. (Ed.): Biotechnology in Agriculture and Forestry, Vol. 7. Medicinal and Aromatic Plants II, Springer Verlag, 1989, 264-285.

HORLEMANN, C.; SCHWEKENDIEK, A.; HÖHNLE, M.; WEBER, G.: Regeneration and Agrobacterium-mediated transformation of hop (Humulus lupulus L.). Plant Cell Rep., 22, 2003, 210-217.

IONKOVA, I.: Biotechnological approaches for the production of lignans. Pharmacognosy Rev., 1, 2007, 57-68.

KAEPPLER, S.M.; PHILLIPS, R.L.: DNA methylation and tissue culture induced variation in plants. In Vitro Cell. Dev. Biol. - Plant, 29, 1993, 125-130.

KRIŠTÍN, J.: Siličnaté rastliny. In: Krištín, J. a kol. (Eds.): Technológia rastlinnej výroby. Príroda, Bratislava, 1987, 96-111.

KUBO, S.; KAGAMI, Y.; NONAKA, K.: Culture of stem tips of the hop and elimination of virus symptoms. Rep. Res. Lab. Kirin Brewing, 18, 1975, 55-62.

LANGEZAAL, C.R.; SCHEFFER, J.J.C.: Initiation and growth characterization of some hop cell suspension cultures. Plant Cell Tissue and Organ Cult., 30, 1992, 159-164.

MILLIGAN, S.R.; KALITA, J.C.; HEYERICK, A.; RONG, H.; DE COOMAN, L.; DE KEUKELEIRE, D.: Identification of a potent phytoestrogen in hops (Humulus lupulus L.) and beer. J. Clin. Endocrinol. Metab., 84, 1999, 2249-2252.

MIRANDA, C.L.; STEVENS, J.F.; HELMRICH, A.; HENDERSON, M.C.; RODRIGUEZ, R.J.; YANG, Y.H.; DEINZER, M.L.; BARNES, D.W.; BUHLER, 
D.R.X.: Anti-proliferative and cytotoxic effects of prenylated flavonoids from hops (Humulus lupulus) in human cancer cell lines. Food Chem. Toxicol., 37, 1999, 271-285.

MOIR, M.: Hops - A Millennium review. J. Am. Soc. Brew. Chem., 58, 2000, 131146.

MOTEGI, T.: Induction of redifferentiated plants from hop leaf callus culture. Proc. Crop Sci. Soc. Jpn, 45, 1976, 175-176.

MURAKAMI, A., DARBY, P., JAVORNIK, B., PAIS, M.S.S., SEIGNER, E., LUTZ, A., SVOBODA, P., Microsatellite DNA analysis of wild hops, Humulus lupulus L. Gen. Res. Crop Evol., 53, 2006, 1553-1562.

NEVE, R.A.: Hops. Chapman and Hall, New York, 1991, 266 pp.

OKADA, Y.; SAEKI, K.; INABA, A.; SUDA, N.; KANEKO, T.; ITO, K.: Construction of gene expression system in hop (Humulus lupulus L.) lupulin gland using valerophenone synthase promoter. J. Plant Physiol., 160, 2003, 1101-1108.

ORINIAKOVÁ, P., MATOUŠEK, J.: Viroid infection of hop (Humulus lupulus L.) mediated by Agrobacterium tumefaciens and conditions for hop transformation. Rostl. Výr., 52, 1996, 233-239.

PAULS, K.P.: Plant biotechnology for crop improvement. Biotech. Adv., 13, 1995, pp. 673-693.

POPOV, V.I.; VYSOTSKII, V.A.; TUKTAGULOV, I.M.: Conditions of cultivation of isolated hop apices for clonal micropropagation. Fiziol. Rast., 32, 1985, 11911195.

PROBASCO, G.; WINSLOW, S.: The use of shoot-tip culture to eliminate viruses from hop varieties grown in the United States. MBAA Tech. Q., 23, 1986, 26-31.

PŠENÁKOVÁ, I.; GAŠPÁRKOVÁ, L.' FARAGÓ, J.: Polyphenol and flavonoid contents of hop callus and cell suspension cultures. Proc. Sci. Comm. IHGC, León, Spain, 2009, 109

RAKOUSKÝ, S.; MATOUŠEK, J.: Direct organogenesis in hop - a prerequisite for an application of A. tumefaciens-mediated transformation. Biol. Plant., 36, 1994, 191-200.

REED, B.M.; OKUT, N.; D'ACHINO, J.; NARVER, L.; DeNOMA, J.: Cold storage and cryopreservation of hops (Humulus L.) shoot cultures through application of standard protocols. Cryo-Letters, 24, 2003, 389-396.

REVILLA, M.A.; MARTÍNEZ, D.: Cryopreservation of Humulus lupulus L. (Hop). In: Towill L.E., Bajaj Y.P.S. (Eds.): Biotechnology in Agriculture and Forestry, Vol. 50 Cryopreservation of Plant Germplasm II. Springer-Verlag, BerlinHeidelberg, 2002, 136-150.

ROBBINS, R.J.; RATCLIFFE, R.G.: Intracellular distribution of phosphate in cultured Humulus lupulus cells growing at elevated exogenous phosphate concentrations. Plant Cell Rep., 3, 1984, 234-236.

ROBBINS, R.J.; FURZE, J.M.; RHODES, M.J.C.: Alpha-acid degradation by suspension culture cells of Humulus lupulus. Phytochemistry, 24, 1985, 709-714.

ROBERTS, M.T.; LEWIS, A.C: Rapid Characterization of Hop Essential Oils Using Gas Chromatography-Time of Flight Mass Spectrometry. J. Am. Soc. Brew. Chem., 60, 2002, 116-121. 
ROY, A.T.; LEGGETT, G.; KOUTOULIS, A.: Development of a shoot multiplication system for hop (Humulus lupulus L.). In Vitro Cell. Dev. Biol. - Plant, 37, 2001, 79-83.

RYBÁČEK, V. (Eds.): Chmelařství. Státní zemědělské nakladatelství Praha, 1980, $426 \mathrm{~s}$.

SAMYN G., WELVAERT W.: Producing a ,nuclear stock“ of virus-free hop plants. Med. Fac. Land Bouww. Rijsunic. Gent, 48, 1983, 877-881.

SCHWEKENDIEK, A.; SPRING, O.; HEYERICK, A.; PICKEL, B.; PITSCH, N.T.; PESCHKE, F.; DE KEUKELEIRE, D.; WEBER, G.: Constitutive expression of a grapevine stilbene synthase gene in transgenic hop (Humulus lupulus L.) yields resveratrol and its derivates in substantial quantities. J. Agric. Food Chem., 55, 2007, 7002-7009.

SMALL, E.: A numerical and nomenclatural analysis of morpho-geographic taxa of Humulus. Syst. Bot., 3, 1978, 37-76.

STAJNER, N.; SATOVIC, Z.; CERENAK, A.; JAVORNIK, B.: Genetic structure and differentiation in hop (Humulus lupulus L.) as inferred from microsatelites. Euphytica, 161, 2008, 301-311.

STEVENS, J.F.; MIRANDA, C.L.; BUHLER, D.R.; DEINZER, M.L.: Chemistry and biology of hop flavonoids. J. Am. Soc. Brew. Chem., 56, 1998, 136-145.

STEVENS, J.F.; TAYLOR, A.W.; DEINZER, M.L.: Quantitative analysis of xanthohumol and related prenylflavonoids in hops and beer by liquid chromatography-tandem mass spectrometry. J. Chromatogr. A, 832, 1999, 97-107.

SVOBODA P.: Kultivace izolovaných vrcholů chmele (Humulus lupulus L.) in vitro. [Culture of isolated shoot tips of hops (Humulus lupulus L.) in vitro.] Rostl. Výr., 38, 1992, 523-528.

ŠKOF, S.; LUTHAR, Z.: Detection of the reporter and selection genes in transformed hop (Humulus lupulus L.). Acta Agricult. Sloven., 85, 2005, 351-358.

TREVISAN, M.T.S.; SCHEFFER, J.J.C.; VERPOORTE, R.: Effect of elicitation on the peroxidase activity in some cell suspension cultures of hop, Humulus lupulus. Plant Cell Tissue Organ Cult., 48, 1997, 121-126.

VERZELE, M.; DE KEUKELEIRE, D.: Chemistry and analysis of hop and beer bitter acids. Elsevier, Amsterdam, 1991.

VILLALOBOS, V.M.; ENGELMANN, F.: Ex situ conservation of plant germplasm usin biotechnology. World J. Microbiol. Biotechnol., 11, 1995, 375-382.

VINE, S.J.; JONES, O.P.: The culture of shoot tips of hop (Humulus lupulus L.) to eliminate viruses. J. Hort. Sci., 44, 1969, 281-284.

WATT, M.P.; THOKOANE, N.L.; MYCOCK, D.; BLAKEWAY, F.: In vitro storage of Eucalyptus grandis germplasm under minimal growth conditions. Plant Cell Tissue Organ Cult., 61, 2000, 161-164.

WILSON, D.G.: Plant remains from the Graveney boat and the early history of Humulus lupulus L. in W. Europe. New Phytol., 75, 1975, 627-648.

ZANOLI, P.; ZAVATTI, M.: Pharmacognostic and pharmacological profile of Humulus lupulus L. J. Ethnopharmacol., 116, 2008, 383-396. 